\title{
Caryospora varaniornati sp. n. (Apicomplexa: Eimeriidae) in the Nile monitor, Varanus (Polydaedalus) niloticus species complex
}

\author{
David Modrý ${ }^{1,2}$, Jan R. Šlapeta ${ }^{1}$, Zdeněk Knotek $^{3}$ and Břetislav Koudela ${ }^{1,2}$ \\ ${ }^{1}$ Department of Parasitology, University of Veterinary and Pharmaceutical Sciences, Palackého 1-3, 61242 Brno, Czech \\ Republic; \\ ${ }^{2}$ Institute of Parasitology, Academy of Sciences of the Czech Republic, Branišovská 31, 37005 České Budějovice, Czech \\ Republic; \\ ${ }^{3}$ Department of Reptiles and Small Mammals, Small Animal Clinic, University of Veterinary and Pharmaceutical Sciences, \\ Palackého 1-3, 61242 Brno, Czech Republic
}

Key words: Caryospora varaniornati, Eimeriidae, coccidia, Varanus niloticus, Varanus ornatus, Varanidae, Reptilia

\begin{abstract}
Parasitological examination of two ornate Nile monitors Varanus ornatus (Daudin, 1803) imported from Benin revealed the presence of a new species of Caryospora. Oocysts of Caryospora varaniornati $\mathrm{sp}$. n. are spherical to slightly subspherical, $12.0(11-12.5) \times 11.5(11-12) \mu \mathrm{m}$, without a micropyle and oocyst residuum, and occasionally possessing one small polar granule. Sporocysts are broadly ellipsoidal, $8.8(8.5-9.5) \times 6.7(6.5-7) \mu \mathrm{m}$; a lentil-like Stieda body is present, ca. $0.5 \times 1$ $\mu \mathrm{m}$; substieda body not visible. Experimental infection of a closely related host, Varanus niloticus (L.), did not lead to the oocyst excretion despite the fact that one of the experimentally inoculated monitors was immunosuppressed by dexamethasone. Histological examination did not reveal stages of coccidian development. Therefore, it is possible that $C$. varaniornati is strictly host specific.
\end{abstract}

Coccidia of the genus Caryospora Léger, 1904 (Apicomplexa: Eimeriidae) are widely distributed among snakes and raptorial birds and only a few species have been described from other hosts. Only two species have been described to date from saurian hosts in contrast to the diversity of these coccidia in snakes, from which 46 caryosporan species are listed (Modrý 1999). In this paper we describe a new Caryospora species from the African monitor lizard Varanus ornatus (Daudin, 1803) (Sauria: Varanidae), a member of the poorly understood Varanus niloticus (L.) species complex.

\section{MATERIALS AND METHODS}

An adult specimen of the ornate Nile monitor, Varanus (Polydaedalus) ornatus from ZOO Brno, at that time hospitalised at the University of Veterinary and Pharmaceutical Sciences, Brno due to a fracture of the hind limb, was parasitologically examined. Based on data provided by the owner (ZOO Brno), the animal originated from a group of wild-caught Nile monitors recently imported by a pet-trader from Benin in West Africa. The hospitalised animal was kept in quarantine in a glass terrarium and fed on day-old chicks and adult laboratory mice. Faecal samples were collected repeatedly from the floor of the cage and submitted for parasitological examination. Later, faecal samples of a cagemate ornate Nile monitor of the same origin were also provided for parasitological examination by ZOO staff. The faecal samples were examined microscopically after concentration by flotation with modified Sheather's sugar solution (s.g. 1.30). Fresh samples containing unsporulated coccidian oocysts were allowed to sporulate in Petri dishes at room temperature $\left(20-23^{\circ} \mathrm{C}\right)$ and examined daily to determine the stage of sporulation. Sporulated oocysts were measured and photographed using Nomarski interference contrast (NIC) optics. Measurements were made using a calibrated ocular micrometer and are reported in micrometres, as means, followed by the ranges in parentheses. Sporulated oocysts were purified by flotation in Sheather's sugar solution and stored in $2.5 \%$ aqueous solution $(\mathrm{w} / \mathrm{v})$ of potassium dichromate at $4{ }^{\circ} \mathrm{C}$ for one month before further use.

Two juvenile, ca. 6 months old, Varanus (Polydaedalus) niloticus were used for experimental infection. Both animals originated from Togo and had been housed separately and were coprologically negative for previous two months. Two days prior the infection, one animal (No. 2) was given 9 $\mathrm{mg} \cdot \mathrm{kg}^{-1}$ of dexamethasone (DEXASON, ICN Galenica, Yugoslavia). Additionally, three severe combined immunodeficient (SCID) mice were used for experimental infection. SCID mice were maintained in an isolation room under pathogen-free conditions and kept as described previously (Vítovec et al. 1997). Immediately before inoculation, sporulated caryosporan oocysts were washed three times by centrifugation in tap water and then incubated for $15 \mathrm{~min}$ with $2.0 \%(\mathrm{v} / \mathrm{v})$ peracetic acid to kill any adherent bacteria. The oocyst suspensions were then washed three times with sterile phosphate-buffered saline (PBS) and the number of oocysts present in each inoculum determined using a haemocytometer. 
Both Nile monitors and SCID mice were inoculated orally with $10^{3}$ sporulated oocysts. Faeces of both Nile monitors were collected irregularly, based on their feeding and defecating habits, and examined by sucrose flotation. SCID mice and Nile monitor treated previously by dexamethasone were euthanised and dissected at 30 days post infection (DPI) (mice) and 90 DPI (monitor). A total of 26 tissue samples (liver, pancreas, gall bladder, spleen, lung, kidney, urinary bladder, brain, tongue, stomach, duodenum, jejunum, ileum, caecum, colon, rectum, eyelid, nose, foot pads, upper cheek, jowl, scrotum, diaphragm and gluteal, triceps brachii and cardiac muscles) from each SCID mouse were excised and fixed in $10 \%$ neutral buffered formalin; samples of gall bladder, liver, stomach, and 8 equidistantly spaced samples of the intestine were collected from the Nile monitor. Fixed tissues were processed for light microscopy using standard methods. Paraffin sections were stained with haematoxylin/eosin (HE) and Giemsa.

\section{RESULTS}

Coprological examination of both ornate Nile monitors, Varanus ornatus, originating from Benin revealed the presence of strongylid eggs and unsporulated coccidian oocysts in all the samples examined.

Both experimentally inoculated Nile monitor lizards Varanus niloticus remained coprologically negative for the consequent three months; histological examinations of one of them (No. 2) revealed no developmental stages of coccidia. Similarly, SCID mice did not develop typical dermal caryosporosis and histological examination of their tissues did not reveal any coccidian parasites.
The recovered coccidium evidently represents a new caryosporan species, which is described below.

\section{Caryospora varaniornati sp. $\mathrm{n}$.}

Figs. 1-4

Oocysts monosporocystic, octozoic, spherical to slightly subspherical, $12.0(11-12.5) \times 11.5(11-12)$, with a shape index (SI) 1.04 (1.0-1.09); micropyle and oocyst residuum absent. A small (ca. 1-1.5) polar granule occasionally present. Oocyst wall smooth, colourless, single-layered, 0.75 thick. Sporocysts broadly ellipsoidal, $8.8(8.5-9.5) \times 6.7(6.5-7)$, with smooth, colourless and unilayered sporocyst wall; SI 1.32 (1.2-1.5). Stieda body present, lentil-like, ca. 0.5 high and 1 wide; substieda body not visible. Sporozoites elongate, each with subspherical refractile body and centrally located nucleus. Sporocyst residuum present, usually as small granules scattered among sporozoites.

T y p e h o st: Ornate Nile monitor, Varanus (Polydaedalus) ornatus (Daudin, 1803) (Sauria: Varanidae).

T y p e 1 o c a 1 i t y : Type-host individuals were imported from Benin, Africa; detailed locality unknown.

T y p e s p e c i m e n s : Phototypes are deposited in Institute of Parasitology, Academy of Sciences of the Czech Republic, České Budějovice; Coll. No. R 170/98.

Site of infection: Unknown.

$\mathrm{S} p$ or u 1 a t i o $\mathrm{n}$ : Exogenous. First fully sporulated oocysts were observed at day 13 .

Preval e n c e : $2 / 2(100 \%)$.

E t y $\mathrm{m}$ o $l$ o $g$ y: The species name varaniornati is made by joining the genitive forms of host generic and specific Latin names (varanus, $-i$, ornatus, $-i$ ).

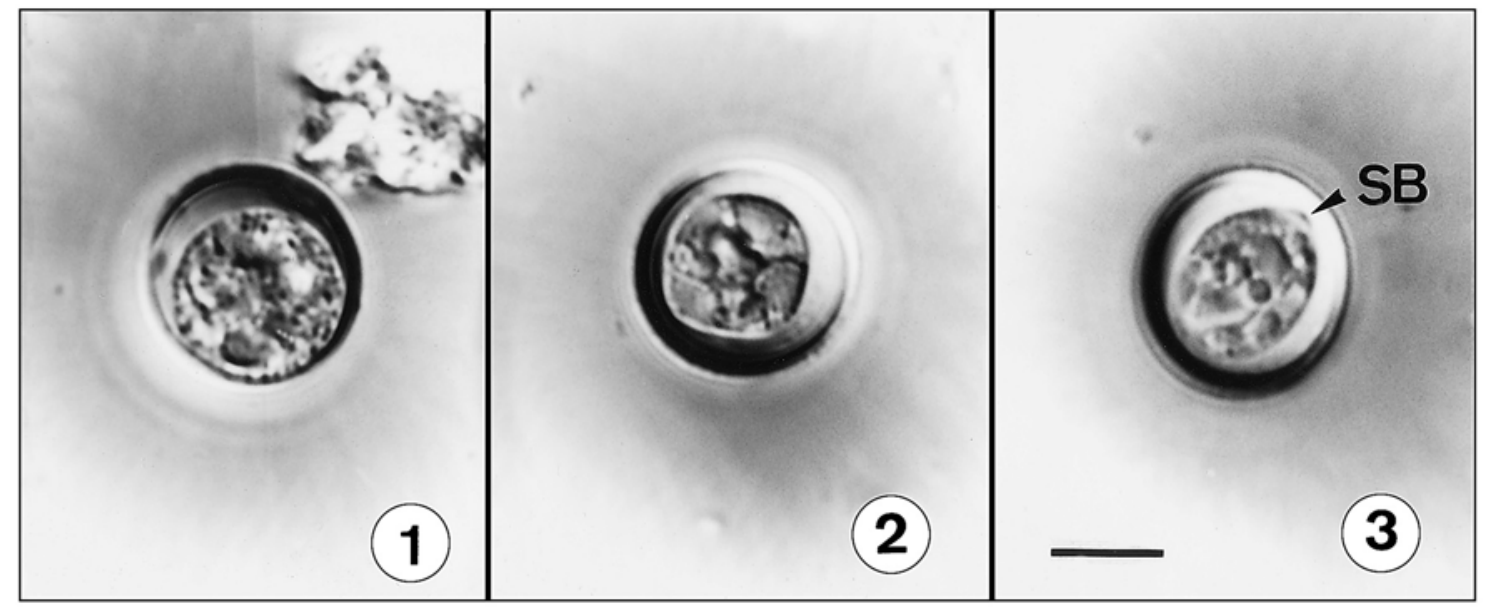

Figs. 1-3. Nomarski interference contrast (NIC) photographs of the oocysts of Caryospora varaniornati sp. $\mathrm{n}$., all in the same scale. Fig. 1. Unsporulated oocyst from fresh faeces. Fig. 2. Oocyst in advanced stage of sporulation, after 9 days. Fig. 3. Sporulated oocyst. SB - Stieda body. Scale bar $=5 \mu \mathrm{m}$. 


\section{DISCUSSION}

Caryosporan coccidia represent relatively common parasites of snakes and raptorial birds from which more than 70 species have been described to date (Upton et al. 1986, 1990, Modrý 1999, Volf et al. 2000). However, the presence of parasites of this genus in saurian hosts is exceptional. Caryospora gekkonis Chakravarty et Kar, 1947 from Gekko gecko (Sauria: Gekkonidae) in India and Caryospora ernsti Upton, Current et Barnard, 1984 from Anolis carolinensis (Sauria: Anolidae) in Northern to Southern America (Chakravarty and Kar 1947, Upton et al. 1984a) are the only species described from saurians. Caryospora gekkonis is easily distinguishable from $C$. varaniornati in having much larger oocysts with distinct micropyle. Although $C$. ernsti is similar in appearance to $C$. varaniornati, it differs in having slightly larger oocyst (11-14.5 vs. $11-12.5)$ and sporocyst (10-12.5 × 7.5-9 vs. 8.5-9.5 $\times 6.5-7)$ dimensions. Additionally, sporocysts of C. ernsti possess a distinct substieda body, which was not seen in the sporocysts of $C$. varaniornati. Both of the aforementioned species are described from hosts that are phylogenetically and geographically distant from the Varanidae.

Kaur and Oberoi (1987) described Caryospora varani from Varanus (Soterosaurus) salvator, (Laurenti) from India. The description is very poor and, based on given data and pictures, this species does not represent a coccidian parasite and as such should be treated as nomen nudum.

The life cycles of the majority of caryosporan coccidia remain unstudied. Two species infecting viperid snakes, Caryospora bigenetica and $C$. simplex, have been found to have heteroxenous life-cycle pattern involving rodents as the so-called secondary hosts (Wacha and Christiansen 1982, Upton et al. 1984b, Upton and Barnard 1988). SCID mice were previously shown to be an optimal model for testing the heteroxenous life-cycle pattern of $C$. simplex from viperid snakes (Modrý et al. 1997, Vítovec et al. 1997, Koudela et al. 2000). Failure to infect these model hosts with $C$. varaniornati suggests the possibility that a heteroxenous pattern of the life cycle involving rodent intermediate/ secondary hosts is unlikely.

Traditionally, monitor lizards of tropical Africa are divided into two species: the steppe monitor, Varanus exanthematicus (Bosc) and the Nile monitor, Varanus niloticus (L.), belonging to two different subgenera (Mertens 1942). Recently, it has been shown that both are closely related and belong to single subgenus Polydaedalus and that both "species" are actually complexes of distinct forms (Böhme 1997). Members of the Varanus niloticus species complex inhabit nearly the entire African continent except for the desert areas. Böhme and Ziegler (1997) mentioned two distinct

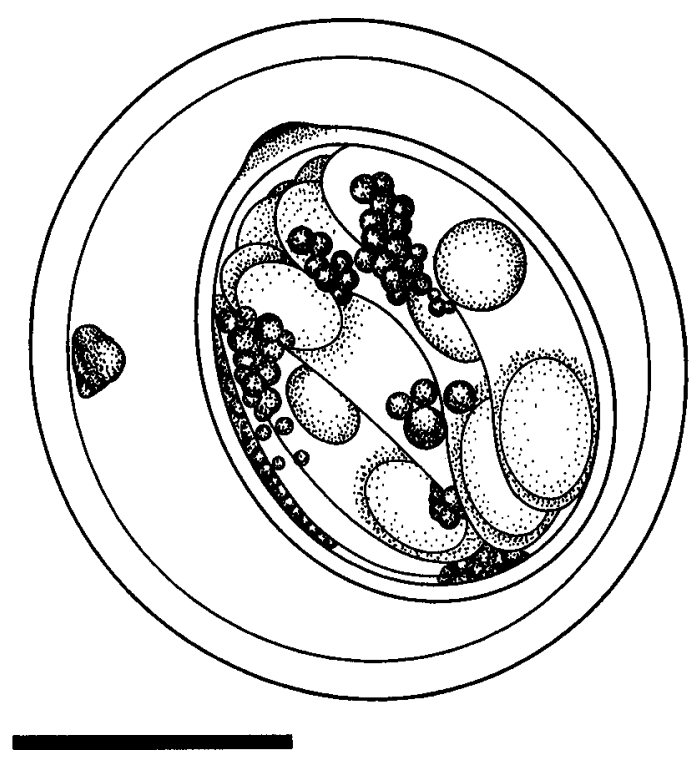

Fig. 4. Composite line drawing of sporulated oocyst of Caryospora varaniornati sp. $\mathrm{n}$. Scale bar $=5 \mu \mathrm{m}$.

species differing in morphological, ecological and distributional characters - Varanus niloticus and $V$. ornatus. In our experiment, we failed to transmit $C$. varaniornati from naturally infected Varanus ornatus to $V$. niloticus; despite the immunosuppression of one experimental animal. The data about host specificity of reptilian coccidia of the family Eimeriidae are scarce; Modrý and Koudela (1995) described in a case of Isospora jaracimrmani the host specificity on the level of single host species. Whereas it is attractive to speculate about the potential strict host specificity of $C$. varaniornati, negative results of the experimental transmission study may also be explained if the oocysts were non-infectious. Experimental infection of $V$. ornatus was impossible due to the unavailability of experimental animals. A life cycle for $C$. varaniornati with an intermediate/secondary host other than murid rodents is possible, but it is premature to postulate a heteroxenous cycle based on the limited data in this study. The life cycle of Caryospora varaniornati therefore remains unknown and needs further research.

Acknowledgements. We are indebted to Dr. S.J. Upton for help in collecting pertinent literature. Dr. J. Mazánek and M. Balcar (ZOO Brno) kindly co-operated in sample collection, L. Hůrková and R. Srnec assisted with the care of experimental monitor lizards. This study was supported by Grant No. A6022903 of the Grant Agency of Academy of Sciences of the Czech Republic. Additional literature cited on the caryosporan coccidia parasitising saurian and ophidian hosts can be found at http://biology001.unm.edu/ coccidia/ home.html 


\section{REFERENCES}

BÖHME W. 1997: Robert Merten's Systematik und Klassifikation der Warane: Aktualisierung seiner 1942er Monographie und eine revidierte Checkliste. Edition Chimaira, Frankfurt am Main, 23 pp.

BÖHME W., ZIEGLER T. 1997: A taxonomic review of the Varanus (Polydaedalus) niloticus (Linnaeus, 1766) species complex. Herpetol. J. 7: 155-162.

CHAKRAVARTY M., KAR A.B. 1947: Observations on two reptilian coccidia. J. R. Asiatic Soc. Bengal Sci. 12: 3-5.

KAUR D., OBEROI R.K. 1987: Studies on protozoan gut fauna of Varanus monitor (carnivorous lizard). Indian Zool. 11: 35-39.

KOUDELA B., MODRÝ D., VOLF J., ŠLAPETA J.R. 2000: SCID mice as a tool for evaluation of heteroxenous life cycle pattern of Caryospora (Apicomplexa, Eimeriidae) species. Vet. Parasitol. 92: 191-198.

MERTENS R. 1942: Die Familie der Warane (Varanidae). Abh. Senckenberg. Naturforsch. Ges. 462: 1-116, 465: 117-234, 466: 235-391.

MODRÝ D., KOUDELA B. 1995: Description of Isospora jaracimrmani sp. n. (Apicomplexa: Eimeriidae) from the Yemen chameleon Chamaeleo calyptratus (Sauria: Chamaeleonidae). Folia Parasitol. 42: 313-316.

MODRÝ D. 1999: The biology and pathogenicity of caryosporan coccidia. PhD Thesis, University of Veterinary and Pharmaceutical Sciences, Brno, 52 pp.

MODRÝ D., KOUDELA B., VOLF J., NEČAS P., HUDCOVIC T. 1997: Vipera berus and V. ammodytes (Serpentes: Viperidae) represent new hosts for
Caryospora simplex (Apicomplexa: Eimeriidae) in Europe. Folia Parasitol. 44: 99-102.

UPTON S.J., BARNARD S.M. 1988: Development of Caryospora bigenetica (Apicomplexa: Eimeriorina) in experimentally infected mice. Int. J. Parasitol. 18: 15-20.

UPTON S.J., CAMPBELL T.W., WEIGEL M., McKOWN R.D. 1990: The Eimeriidae of raptors: review of the literature and description of new species of the genera Caryospora and Eimeria. Can. J. Zool. 68: 1256-1265.

UPTON S.J., CURRENT W.L., BARNARD S.M. 1984a: A new species of Caryospora (Apicomplexa: Eimeriorina) from the green lizard, Anolis carolinensis. Trans. Am. Microsc. Soc. 103: 245-248.

UPTON S.J., CURRENT W.L., BARNARD S.M. 1986: A review of the genus Caryospora Léger, 1904 (Apicomplexa: Eimeriidae). Syst. Parasitol. 8: 3-21.

UPTON S.J., CURRENT W.L., ERNST J.V., BARNARD S.M. 1984b: Extraintestinal development of Caryospora simplex (Apicomplexa: Eimeriidae) in experimentally infected mice, Mus musculus. J. Protozool. 31: 392-398.

VÍTOVEC J., KOUDELA B., MODRÝ D. 1997: Pathogenicity of experimental caryosporosis. Int. J. Parasitol. 27: 819-824.

VOLF J., KOUDELA B., MODRÝ D. 2000: Two new species of Caryospora Léger, 1904 (Apicomplexa: Eimeriidae) from accipitrid raptors. Syst. Parasitol. 46: 23-27.

WACHA R.S., CHRISTIANSEN J.L. 1982: Development of Caryospora bigenetica $\mathrm{n}$. sp. (Apicomplexa, Eimeriidae) in rattlesnakes and laboratory mice. J. Protozool. 29: 272278.

Accepted 11 September 2000 